\title{
ESENSI PESERTA DIDIK: PERSPEKTIF FALSAFAH PENDIDIKAN ISLAM
}

\author{
Abdul Salam Pulungan \\ Mahasiswa Pascasarjana IAIN Padangsidimpuan \\ Jalan T. Rizal Nurdin KM. 4,5 Sihitang Padangsidimpuan \\ E-mail: salampulungan@yahoo.co.id
}

\begin{abstract}
Abstrak
Dalam perspektif falsafah pendidikan Islam semua orang adalah peserta didik, karena, pada kenyataannya, semua manusia selalu dalam proses pembangunan menuju kesempurnaan. Konsep pendidikan Islam tentang peserta didik, khususnya teori fitrah, menyatakan bahwa peserta didik, pada hakekatnya, ketika lahir telah membawa bakat dan potensi yang cenderung kebaikan dan kebenaran. Potensi ini pada dasarnya dapat berkembang dalam keterikatan dengan dunia luar. Sekalipun konsep teori fitrah mengakui bahwa potensi atau daya-daya yang dimiliki peserta didik secara kodrati memang memiliki keaktifan, akan tetapi membiarkannya tumbuh secara alamiah berdasarkan kodratnya sendiri, sangat memungkinkan pertumbuhannya tidak seperti yang diharapkan. Untuk mencapai hasil yang maksimal dalam proses pendidikan, seorang anak didik dituntut untuk memenuhi kode etik tertentu, baik secara langsung maupun tidak langsung. Di samping itu, seorang anak didik/peserta didik harus berniat secara ikhlas dalam menuntut ilmu, karena niat itu merupakan dasar bagi setiap amal perbuatan.
\end{abstract}

\begin{abstract}
In the perspective of the philosophy of Islamic education, the fact that all people are learners. Because, in fact, all human beings are always in the process of development toward perfection. The concept of Islamic education on the learner ascertains that learners basically birth has brought talent and potential that tends to goodness and truth. These potentials can essentially develop in an entanglement with the external world. Although the theory of fitrah recognizes that the potential or owned power learners are naturally does have liveliness, but let it grow naturally by its very nature, it is possible growth was not as expected. To achieve maximum results in the educational process, a protege required to meet certain code of conduct, either directly or indirectly. The student is intending in their studies, since the intention was to form the basis for any charity action.
\end{abstract}

Kata Kunci: Peserta Didik, Esensi, Potensi/Fitrah 


\section{Abdul Salam Pulungan}

\section{Pendahuluan}

Peserta didik tidak hanya sekedar objek pendidikan, tetapi pada saat-saat tertentu ia akan menjadi subjek pendidikan. Hal ini menunjukkan bahwa posisi peserta didik tidak hanya sekedar pasif laksana cangkir kosong yang siap menerima air kapan dan dimanapun, tetapi peserta didik juga aktif, kreatif dan dinamis dalam berinteraksi dengan pendidiknya dalam upaya pengembangan keilmuannya.

Eksistensi peserta didik sebagai salah satu sub sistem pendidikan Islam sangat menentukan dalam keberhasilan pendidikan. Tidak mungkin pelaksanaan pendidikan Islam tidak bersentuhan dengan individu-individu yang berkedudukan sebagai peserta didik. Pendidik tidak mempunyai arti apa-apa tanpa kehadiran peserta didik. Dengan demikian, dapat dikatakan bahwa peserta didik adalah kunci yang menentukan terjadinya interaksi edukatif, yang pada gilirannya sangat menentukan kualitas pendidikan Islam.

Dalam pembahasan makalah ini akan dijelaskan mengenai hal-hal yang menyangkut dengan peserta didik dalam persfektif filsafat pendidikan Islam yang dimulai dari Bab I Pendahuluan sampai pada Bab III kesimpulan dan sara, semoga menjadi bahan untuk menambah wawasan dan prakteknya dalam kehidupan sehari-hari.

\section{Pengertian Peserta Didik}

Istilah "peserta didik" mempunyai sejumlah sinonim, Abuddin Nata menyatakan bahwa istilah peserta didik adalah "murid"1, sedangkan Syafaruddin mengistilahkan dengan "anak didik", ${ }^{2}$ juga terdapat istilahistilah lainnya. Namun demikian dalam karya tulis ini istilah tersebut disamakan dengan "peserta didik".

Peserta didik adalah subjek pendidikan, karena merekalah yang belajar, memiliki tujuan dan pewarisan masa depan. Secara konsepsional

\footnotetext{
${ }^{1}$ Abuddin Nata, Persfektif Islam Tentang Pola Hubungan Guru Murid (Jakarta: Raja Grafindo Persada, 2001), hlm. 49.

2Syafaruddin dkk., IImu Pendidikan Islam (Jakarta: Hijri Pustaka Utama, 2006), hlm. 61.
} 
dan operasional perhatian pendidikan di berbagai negara di dunia ini lebih dipusatkan kepada pengembangan Sumber Daya Manusia (SDM) secara holistik. Konsep ini menjelaskan bahwa manusia bukan saja bertindak sebagai pemimpin (khalifah) dalam seluruh proses, tetapi juga sebagai pelaksana dan pada akhirnya sebagai penerima hasil. Peran utama ini dimainkan melalui kegiatan yang disebut memilih, atau membuat pilihan dan berbagai alternatif yang berbeda dalam usaha mencapai sasaran yang telah ia tetapkan. Perannya untuk membuat pilihan ini tampaknya tidak dapat dielakkan oleh manusia dalam pelaksanaan berbagai fungsi utamanya. ${ }^{3}$

Berbicara tentang peserta didik, dengan berpijak pada paradigma "belajar sepanjang masa" maka istilah yang tepat untuk menyebut indivudu yang menuntut ilmu adalah peserta didik dan bukan anak didik. Peserta didik cakupannya lebih luas, yang tidak hanya melibatkan anak-anak, tetapi juga pada orang-orang dewasa. Sementara istilah anak didik hanya khusus bagi individu yang berusia kanak-kanak. Penyebutan peserta didik ini juga mengisyaratkan bahwa lembaga pendidikan tidak hanya di sekolah (pendidikan formal), tapi juga lembaga pendidikan di masyarakat, seperti majelis taklim, paguyuban, dan sebagainya. ${ }^{4}$

Peserta didik dalam pendidikan Islam adalah individu sedang tumbuh dan berkembang, baik secara fisik, psikologis, sosial dan religious dalam mengarungi kehidupan di dunia dan di akhirat kelak. Defenisi tersebut memberi arti bahwa peserta didik merupakan individu yang belum dewasa, yang karenanya memerlukan orang lain untuk menjadikan dirinya dewasa. Anak adalah peserta didik dalam keluarga, murid adalah peserta didik di sekolah, anak-anak penduduk adalah peserta didik dalam masyarakat sekitarnya, dan umat beragama menjadi peserta didik ruhaniawan dalam suatu agama. ${ }^{5}$

${ }^{3}$ M. Irsyad Djuwaeli, Pembaruan Kembali Pendidikan Islam (Ciputat: Karsa Utama Mandiri dan PB Mathla'ul Anwar, 1998), hlm. 22.

${ }_{4}$ Abdul Mujib, Ilmu Pendidikan Islam (Jakarta: Fajar Interpratama Offset, 2008), hlm. 103.

$5 /$ bid. 


\section{Abdul Salam Pulungan}

Peserta didik merupakan salah satu komponen dalam sistem pendidikan Islam. Peserta didik merupakan "raw material' (bahan mentah) di dalam proses transformasi pendidikan yang berbeda dengan komponenkomponen lain. Komponen ini berbentuk "material" sudah setengah jadi, sedangkan komponen-komponen lain dapat dirumuskan dan disusun sesuai dengan keadaan fasilitas dan kebutuhan yang ada.

Peserta didik secara formal adalah orang yang berada pada fase pertumbuhan dan perkembangan, baik secara fisik maupun psikis. Pertumbuhan dan perkembangan merupakan ciri dari seorang peserta didik yang perlu bimbingan dari seorang pendidik. Dalam hal ini, pertumbuhan menyangkut fisik, sedangkan perkembangan menyangkut psikis. ${ }^{6}$

Menurut pasal 1 ayat 4 UU RI No. 20 Tahun 2003 tentang sistem pendidikan Nasional, peserta didik adalah anggota masyarakat yang berusaha mengembangkan dirinya melalui proses pendidikan pada jalur jenjang dan jenis pendidikan tertentu.

Syamsul Nizar menjelaskan beberapa diskripsi tentang hakikat peserta didik dan implikasinya terhadap pendidikan Islam, yaitu:

1. Peserta didik bukan merupakan miniatur orang dewasa, akan tetapi memiliki dunianya sendiri. Hal ini sangat penting untuk dipahami agar perlakuan terhadap mereka dalam proses kependidikan tidak disamakan dengan pendidikan orang dewasa, baik dalam aspek metode mengajar, materi yang akan diajarkan, sumber bahan yang akan digunakan, dan lain sebagainya.

2. Peserta didik adalah manusia yang memiliki diferensiasi periodisasi perkembangan dan pertumbuhan. Pemahaman ini perlu untuk diketahui, agar aktivitas kependidikan Islam disesuaikan dengan tingkat pertumbuhan dan perkembangan yang ada pada umumnya dilalui oleh setiap peserta didik. Hal ini sangat beralasan, karena kadar kemampuan peserta didik ditentukan oleh faktor usia dan periode perkembangan atau pertumbuhan potensi yang dimilikinya.

${ }^{6}$ Ramayulis, IImu Pendidikan Islam (Jakarta: Radar Jaya Offset, 2008), hlm. 77. 
3. Peserta didik adalah manusia yang memiliki kebutuhan, baik yang menyangkut kebutuhan jasmani maupun rohani yang harus dipenuhi. Diantara kebutuhan tersebut adalah: kebutuhan biologis, kasih sayang, rasa aman, harga diri, realisasi diri, dan lain sebagainya. Semua itu penting dipahami oleh pendidik agar tugas-tugas kependidikannya dapat berjalan secara baik dan lancar.

4. Peserta didik adalah makhluk Allah yang memiliki perbedaan individual (differensiasi individua), baik yang disebabkan oleh faktor pembawaan maupun lingkungan tempat ia berada. Pemahaman tentang differensiasi individual peserta didik sangat penting untuk dipahami oleh seorang pendidik. Hal ini disebabkan karena menyangkut pendekatan yang perlu dilakukan pendidik dalam menghadapi ragam sikap dan perbedaan tersebut dalam suasana yang dinamis, tanpa harus mengorbankan kepentingan salah satu pihak atau kelompok.

5. Peserta didik merupakan resultan dari dua unsur utama, yaitu jasmani dan rohani. Unsur jasmani memiliki daya fisik yang menghendaki latihan dan pembiasaan yang dilakukan melalui proses pendidikan. Sementara unsur rohani memiliki dua daya, yaitu daya akal dan daya rasa. Untuk mempertajam daya akal, maka proses pendidikan hendaknya diarahkan untuk mengasah daya intelektualitasnya melalui ilmu-ilmu rasional. Adapun untuk mempertajam daya rasa dapat dilakukan melalui pendidikan akhlak dan ibadah. Konsep ini bermakna bahwa suatu proses pendidikan Islam hendaknya dilakukan dengan memandang peserta didik secara utuh. Pada tataran praktis, pendidikan Islam bukan hanya mengutamakan pendidikan salah satu aspek saja, melainkan kedua aspek secara integral dan harmonis. Bila tidak, maka pendidikan tidak akan mampu menciptakan out put yang memiliki kepribadian utuh, akan tetapi malah sebaliknya yaitu kepribadian yang ambigu. ${ }^{7}$ Apabila hal ini terjadi dalam praktek pendidikan Islam, maka untuk mencapai manusia yang seutuhnya yakni insan kamil tidak akan tercapai.

7 Samsul Nizar, Filsafat Pendidikan Islam Pendekatan Historis, Teoritis, dan Praktis (Jakarta Selatan: Ciputat Pers, 2002), hlm. 49. 


\section{Abdul Salam Pulungan}

6. Peserta didik adalah manusia yang memiliki potensi (fitrah) yang dapat dikembangkan secara dinamis. Tugas pendidik adalah membantu mengembangkan dan mengarahkan perkembangan tersebut sesuai dengan tujuan pendidikan yang diinginkan, tanpa melepaskan tugas kemanusiaanya, baik secara vertikal maupun horizontal. Ibarat sebidang sawah, peserta didik adalah orang yang berhak bercocok tanam dan memanfaatkan sawahnya (potensi). Sementara pendidik (termasuk orang tua) hanya bertugas menyirami dan mengontrol tanaman agar tumbuh subur sebagaimana mestinya, sesuai dengan nilai-nilai yang berlaku. ${ }^{8}$

Dengan demikian, pada hakikatnya semua manusia adalah peserta didik, sebab semua manusia adalah makhluk yang senantiasa berada dalam proses perkembangan menuju kesempurnaan, atau suatu tingkatan yang dipandang sempurna, dan proses itu berlangsung sepanjang hayat.

\section{Esensi Peserta Didik dalam Perspektif Falsafah Pendidikan Islam}

Allah Swt, sebagai murabbi, mu'allim, atau muaddib, pada hakikatnya, adalah pendidik bagi seluruh makhluk ciptaan-Nya. Dialah yang mencipta dan memelihara seluruh makhluk. Pemeliharaan Allah Swt mencakup sekaligus kependidikan-Nya, baik dalam arti tarbiyah, ta'alim, maupun ta'adib. Karenanya, dalam perspektif falsafah pendidikan Islam, peserta didik itu mencakup seluruh makhluk Allah Swt, seperti malaikat, jin, manusia, tumbuhan, hewan, dan sebagainya.

Namun, dalam arti khusus, peserta didik adalah seluruh al-insan, albasyar, atau bany adam yang sedang berada dalam proses perkembangan menuju kepada kesempurnaan atau suatu kondisi yang dipandang sempurna (al-Insan al-Kami). Terma al-Insan, al-basyar, atau bany adam dalam defenisi ini memberi makna bahwa kedirian peserta didik itu tersusun dari unsur-unsur jasmani, ruhani, dan memiliki kesamaan universal, yakni sebagai makhluk yang diturunkan atau dikembangbiakan dari Adam a.s. Kemudian, terma perkembangan dalam pengertian ini berkaitan dengan proses mengarahkan kedirian peserta didik, baik diri fisik

${ }^{8}$ Samsul Nizar, Filsafat Pendidikan Islam ..., hlm. 50. 
(jismiyah) maupun diri psikis (ruhiyah): aql, nafs, qalb, agar mampu menjalankan fungsi-fungsinya secara sempurna.

Ketika dilahirkan, fisik manusia dalam keadaan lemah dan belum mampu mengambil atau memegang benda dan kaki belum mampu melangkah atau berjalan. ${ }^{9}$ Demikian juga 'aq/ manusia belum dapat difungsikan untuk menalar baik-buruk atau benar-salah. Melalui proses ta'lim, tarbiyah, atau ta'dib, secara bertahap, 'aq/ manusia diasah, dilatih, dan dibimbing melakukan penalaran yang logis atau rasional, sehingga ia mampu menyimpulkan baik-buruk atau benar-salah. Demikiah juga nafs, ia hanya cenderung pada pemenuhan kehendak atau kebutuhan jismiyah, terutama makan-minum. Melalui proses ta'lim, tarbiyah atau ta'dib, nafs manusia dilatih dan dibimbing untuk melakukan pengendalian, pemeliharaan, dan pensucian diri. Demikian juha halnya qalb, ia hanya potensi laten yang belum mampu menangkap cahaya (al-nur) dan memahami kebenaran (al-haqq). Kemudian, melalui proses ta'lim, tarbiyah atau ta'dib, qalb manusia dibimbing sehingga mampu menangkap cahaya (al-nur) dan memahami kebenaran (al-haqq) serta hidup sesuai dengan cahaya dan kebenaran tersebut.

Dalam pengertian di atas, yang dimaksud dengan kesempurnaan adalah suatu keadaan dimana dimensi jismiyah dan ruhiyah peserta didik, melalui proses ta-lim, tarbiyah, atau ta'dib, diarahkan secara bertahap dan berkesinambungan untuk mencapai tingkatan terbaik dalam kemampuan mengaktualisasikan seluruh daya atau kekuatannya (quwwah al-jismiyah wa al-ruhiyah). Dalam perspektif ini, secara sederhana, kesempurnaan dimensi jismiyah adalah suatu kondisi dimana seluruh unsur atau anggota jasmani manusia mencapai tingkatan terbaik dalam kemampuannya melakukan tugas-tugas fisikal-biologis, seperti bergerak, berpindah dan melakukan berbagai aktivitas fisikal lainnya. Demikian pula halnya dengan kesempurnaan dimensi ruhiyah. ' $A q l$, nafs, dan qalb peserta didik mencapai tingkatan terbaik dalam berpikir atau menalar (al-aql al-

9Al-Rasyidin, Falsafah Pendidikan Islami: Membangun Kerangka Ontologi, Epistomologi dan Aksiologi Praktik Pendidikan (Bandung: Cipta Pustaka Media Perintis, 2008), Cet. I, hlm. 148. 


\section{Abdul Salam Pulungan}

mustasyfad) dalam mengendalikan dan mensucikan diri (al-nafs almuthmainnah), dan dalam menangkap cahaya dan memahami kebenaran (qalb al-salim).

\section{Potensi/Fitrah Peserta Didik}

Tingkat dan jenis karakteristik peserta didik, baik ranah kognitif, afektif, psikomotorik, maupun fitrah berupa bakat, minat, kecendrungan lainnya yang dimilikinya sejak lahir adalah berbeda-beda. ${ }^{10}$ Peserta didik merupakan orang yang belum dewasa dan memiliki sejumlah potensi (kemampuan) dasar yang masih perlu dikembangkan. Peserta didik merupakan makhluk Allah yang memiliki fitrah jasmani maupun rohani yang belum mencapai taraf kematangan baik bentuk, ukuran, maupun perimbangan pada bagian-bagian lainnya. Dari segi rohaniah, ia memiliki bakat, memiliki kehendak, perasaan, dan pikiran yang dinamis dan perlu dikembangkan.

Oleh karena itu. peserta didik merupakan subjek dan objek pendidikan yang memerlukan bimbingan orang lain (pendidik) untuk membantu mengarahkannya mengembangkan potensi yang dimilikinya, serta membimbingnya menuju kedewasaan. Potensi suatu kemampuan dasar yang dimilikinya tidak akan tumbuh dan berkembang secara optimal tanpa bimbingan pendidik. ${ }^{11}$

Konsep pendidikan Islam tentang peserta didik berlandaskan pada konsep atau teori fitrah, yang mengetengahkan bahwa pada dasarnya peserta didik lahir telah membawa bakat dan potensi-potensi yang cenderung pada kebaikan dan kebenaran. Potensi-potensi tersebut pada hakikatnya dapat berkembang dalam suatu keterjalinan dengan dunia eksternalnya, yang dapat diformulasikan dengan rentangan“baik-interaktif" (good interaktif).

Jika konsep ini dihadapkan pada wawasan teoritik yang mengkonsepsikan perkembangan peserta didik sebagai: (1) netral-pasif,

10Abuddin Nata, Persfektif Islam tentang Strategi Pembelajaran (Jakarta: Kencana, 2009), hlm. 111.

${ }^{11}$ Samsul Nizar, Filsafat Pendidikan Islam ..., hlm. 47. 
(2) baik/buruk-interaktif, buruk-aktif,(4) baik-aktif, maka pertama sekali konsep ini akan menolak teori yang dikembangkan oleh Theistic Mental Discipline yang memandang peserta didik memiliki sifat dasar bad-active, sebagaimana Islam menolak konsep "dosa warisan" yang diyakini oleh umat Nasrani. ${ }^{12}$

Islam mengakui keabsahan kisah kejatuhan Nabi Adam as, yang menyebabkan harus dipindahkan dari surga, tempat yang menyenangkan itu, sebagai akibat dari pada dosa yang diperbuatnya karena terpengaruh rayuan Iblis untuk memakan buah khuldi, yang sebelumnya telah diperingatkan Tuhan agar tidak mendekati pohon tersebut.

Adam segera menyadari kesalahannya dan memohon ampun Tuhan. Dengan taubat yang sungguh-sungguh, dosa-dosa Adam as telah diampuni oleh Tuhan. Hal inilah yang menjadi pangkal keyakinan bahwa tak ada dosa yang diwariskan kepada anak cucunya, malahan sebaliknya, Islam meyakini bahwa setiap manusia suci dari dosa dan kesalahan. Bahkan lebih dari itu, manusia dalam pandangan Islam memiliki fitrah beragama (bertauhid), sebagaimana dijelaskan Nabi Muhammad saw dalam hadisnya, bahwa": Tak seorangpun diantara manusia yang dilahirkan ke dunia ini kecuali atas dasar fitrah; kedua orangtuanyalah yang memungkinkannya menjadi Yahudi, Nasrani atau Majusi. ${ }^{13}$

Pribadi manusia terdiri dari jasmani, rohani/jiwa dan intelek. Semua potensi itu mendorong seorang anak cenderung kepada keimanan kepada Allah atau fitrah beragama. ${ }^{14}$ Berkenaan dengan fitrah, Ahmad Musthafa al-Maraghi menjelaskan bahwa fitrah adalah sesuatu dimana Allah telah menciptakan manusia atasnya, seperti kesiapan menerima kebenaran dan kesanggupan mengetahuinya. ${ }^{15}$

${ }^{12}$ Dja'far Siddik, Konsep Dasar IImu Pendidikan Islam (Bandung: Citapustaka Media, 2006), hlm. 63-64.

13/bid., hlm. 65

${ }^{14}$ Syafaruddin dkk, IImu Pendidikan Islam (Jakarta Selatan: Hijri Pustaka Utama), hlm. 62.

15 Yunus Namsa, Metodologi pengajaran Agama Islam (Jakarta: Pustaka Firdaus, 2000), hlm. 130. 


\section{Abdul Salam Pulungan}

Fitrah manusia tidak akan berkembang dan tumbuh dengan baik tanpa adanya bimbingan faktor dari luar (eksogen). Faktor eksogen yang paling strategis untuk menumbuh kembangkan potensi manusia adalah lewat pendidikan.Karenanya, pendidikan harus memandang anak didik sebagai orang yang belum dewasa dan sedang dalam masa perkembangannya menuju pada kedewasaannya. ${ }^{16}$

Secara singkat dapat dikatan, bahwa peserta didik dalam pandangan Islam memang memiliki daya atau potensi untuk berkembang dan siap pula untuk dikembangkan. Oleh karena itu setiap peserta didik tidak dapat diperlakukan sebagai manusia yang sama sekali pasif, melainkan memiliki kemampuan dan keaktifan yang mampu membuat pilihan dan penilaian, menerima, menolak atau menemukan alternatif lain yang lebih sesuai dengan pilihannya sebagai perwujudan dari adanya kehendak dan kemauan bebasnya. ${ }^{17}$

Dengan baiknya lingkungan anak (peserta didik) akan membuat anak berada dalam fitrahnya serta berkembang dengan baik, sehingga nantinya menjadi manusia yang beriman dan manusia seutuhnya (insan kami).

\section{Tugas dan Tanggung jawab Peserta Didik}

Berkenaan dengan tugas utama yang haru dilakukan peserta didik ini, Nabi Muhamamd Saw melalui salah satu hadisnya menegaskan bahwa menuntut ilmu merupakan kewajiban bagi setiap Muslim dan Muslimat. Proses menuntut atau mempelajari al-ilm itu dapat dilakukan dengan berbagai cara, seperti membaca, baik yang tersurat maupun tersirat; mengeksplorasi, meneliti, dan mencermati fenomenadiri, atau menalar; berdialog. Berdiskusi atau bermusyawarah; mencontoh atau meneladani; mendengarkan nasehat, bimbingan, pengajaran, dan peringatan; memetik 'ibrah atau hikmah; melatih atau membiasakan diri, dan masih banyak lagi

16 Khoiron Rosyadi, Pendidikan Profetik (Yogyakarta: Pustaka Pelajar, 2004), hlm. 198-199.

17 Dja'far siddik, Konsep Dasar IImu Pendidikan Islam.., hlm. 70. 
aktivitas belajar lainnya yang harus dilakukan setiap peserta didik untuk meraih al'ilm dan mengamalkannya dalam kehidupan. ${ }^{18}$

Berkenaan dengan tanggung jawab, dalam perspektif falsafah pendidikan Islam, tanggung jawab utama peserta didik adalah memelihara agar semua potensi yang dianugerahkan Allah Swt kepadanya dapat diberdayakan sebagaimana mestinya. Dimensi jismiyah wajib dipelihara agar secara fisikal peserta didik mampu melakukan aktivitas belajar, meskipun harus melakukan rihlah ke berbagai tempat. Demikian pula dimensi ruhiyah juga wajib dipelihara, agar bisa difungsikan sebagai energi atau kekuatan untuk melakukan aktivitas belajar. ${ }^{19}$ Untuk itu, dimensi jismiyah dan ruhiyah ini perlu diperhatikan sehingga siap untuk mengikuti proses belajar dengan baik.

Menurut Asma Hasan Fahmi bahwa tugas dan kewajiban peserta didik yang perlu dipenuhi adalah:

1. Peserta didik hendaknya senantiasa membersihkan hatinya sebelum menuntut ilmu. Hal ini disebabkan karena belajar adalah ibadah dan tidak sah ibadah kecuali dengan hati yang bersih.

2. Tujuan belajar hendaknya ditujukan untuk menghiasi ruh dengan berbagai sifat keutamaan.

3. Memiliki kemauan yang kuat untuk mencari dan menuntut ilmu di berbagi tempat.

4. Setiap peserta didik wajib menghormati pendidiknya.

5. Peserta didik hendaknya belajar secara sungguh dan tabah dalam belajar. ${ }^{20}$

\section{Sifat-Sifat Peserta Didik}

Sejalan dengan tujuan pendidikan sebagai upaya mendekatkan diri kepada Allah Swt., maka belajar termasuk ibadah. Dengan dasar pemikiran ini, maka seorang murid yang baik, adalah murid yang memiliki ciri-ciri sebagai berikut:

\footnotetext{
${ }^{18}$ Al Rasyidin, Falsafah Pendidikan Islami ..., hlm. 152.

19 Al Rasyidin, Falsafah Pendidikan Islami ..., hlm. 153.

20 Samsul Nizar, Filsafat Pendidikan Islami ..., hlm. 51.
} 


\section{Abdul Salam Pulungan}

Pertama, seorang murid harus berjiwa bersih, terhindar dari budi pekerti yang hina dina dan sifat-sifat tercela lainnya. Sebagai mana halnya shalat, maka menuntut ilmu pun demikian juga. la harus dilakukan dengan hati yang bersih, terhindar dari hal-hal jelek dan kotor, termasuk didalamnya sifat-sifat yang rendah seperti marah, sakit hati, dengki, tinggi hati, 'ujub, takabbur dan sebagainya. ${ }^{21}$

Kedua seorang murid yang baik, juga harus menjauhkan diri dari persoalan-persoalan duniawi, mengurangi keterikatan kepada dunia, karena keterikatan kepada dunia dan masalah-masalahnya dapat mengganggu lancarnya penguasaan ilmu.

Ketiga, seorang murid yang baik hendaknya bersikap rendah hati atau tawadlu. Sifat ini begitu amat ditekankan oleh Al-Ghazali. la menganjurkan agar jangan ada murid yang merasa lebih besar dari pada gurunya.

Keempat, khusus terhadap murid yang baru hendaknya jangan mempelajari ilmu-ilmu yang saling berlawanan, atau pendapat yang saling berlawanan atau bertentangan.

Kelima, seorang murid yang baik hendaknya mendahulukan mempelajari yang wajib. Pengetahuan yang menyangkut berbagai segi (aspek) lebih baik dari pada pengetahuan yang menyangkut hanya satu segi saja. Mempelajari al-Qur'an misalnya harus didahulukan, karena dengan menguasai al-Qur'an dapat mendukung pelaksanaan ibadah, serta memahami ajaran Islam secara keseluruhan, mengingat al-Qur'an adalah sumber utama ajaran Islam. ${ }^{22}$

Keenam, seorang murid yang baik hendaknya mempelajari ilmu secara bertahap. Seorang murid dinasehatkan agar tidak mendalami ilmu secara sekaligus, tetapi memulai dari ilmu-ilmu agama dan menguasainya dengan sempurna. Setelah itu, barulah ia melangkah kepada ilmu-ilmu lainnya.

${ }^{21}$ Abuddin Nata, Pemikiran Para Toko pendidikan Islam Seri Kajian Filsafat Pendidikan Islam (Jakarta: Raja Grafindo Persada, 2001), hlm. 99-101

22 /bid. 
Ketujuh, seorang murid hendaknya tidak mempelajari satu disiplin ilmu sebelum menguasai disiplin ilmu sebelumnya. Sebab ilmu-ilmu itu tersusun dalam uraian tertentu secara alami, sebagiannya merupakan jalan menuju kepada sebagian yang lain.

Kedelapan, seorang murid hendaknya juga mengenal nilai setiap ilmu yang dipelajarinya. Kelebihan dari masing-masing ilmu serta hasilhasilnya yang mungkin dicapai hendaknya dipelajari dengan baik. Dalam hubungan ini, al-Ghazali mengatakan bahwa nilai ilmu itu tergantung pada dua hal, yaitu hasil dan argumentasinya. ${ }^{23}$

Berkenaan dengan sifat peserta didik, Imam al-Ghazali, sebagaimana dikutip Fatahiyah Hasan Sulaiman, merumuskan sifat-sifat yang patut dan harus dimiliki peserta didik kepada 10 (sepuluh) macam sifat, yaitu:

1. Belajar dengan niat ibadah dalam rangka taqarrub ila Allah. Konsekuensi dari sikap ini, peserta didik akan senantiasa mensucikan diri dengan akhlaqul al-karimah dalam kehidupan sehari-harinya, serta berupaya meninggalkan watak dan akhlak yang rendah (tercela) sebagai refleksi atas Q.S. al-An'am/6: 162 dan Adz Dzariyat/51: 56.

2. Mengurangi kecenderungan pada kehidupan duniawi dibandingkan ukhrawi atau sebaliknya. Sifat yang ideal adalah menjadikan kedua dimensi kehidupan (dunia-akhirat) sebagai alat yang integral untuk melaksanakan amanah-Nya, baik secara vertikal maupun horizontal. ${ }^{24}$

3. Anak didik harus selalu bersikap rendah hati, memperhatikan instruksi dan arahan pendidik, dan mampu mengontrol emosinya ${ }^{25}$.

4. Menjaga pikiran dari berbagai pertentangan yang timbul dari berbagai aliran. Dengan pendekatan ini, peserta didik akan melihat berbagai pertentangan dan perbedaan pendapat-pendapat sebagai sebuah

\footnotetext{
$23 /$ bid.

24 /bid.

${ }^{25}$ Asrorun Niam Sholeh, Reorientasi Pendidikan Islam Mengurai Relevansi Konsep al-Ghazali dalam Konteks Kekinian (Jakarta, 2004), hlm. 76.
} 


\section{Abdul Salam Pulungan}

dinamika yang bermanfaat untuk menumbuhkan wacana intelektual, bukan sarana saling menuding dan menganggap diri paling benar. ${ }^{26}$

5. Mempelajari ilmu-ilmu yang terpuji, baik ilmu umum maupun agama.

6. Belajar secara bertahap atau berjenjang dengan memulai pelajaran yang mudah (konkrit) menuju pelajaran yang sulit (abstrak); atau dari ilmu yang fardhu 'ain menuju ilmu yang fardhu kifayah (Q.S. alFath/48:19).

7. Mempelajari suatu ilmu sampai tuntas untuk kemudian beralih pada ilmu lainnya. Dengan cara ini, peserta didik akan memiliki spesifikasi ilmu pengetahuan secara mendalam.

8. Memahami nilai-nilai ilmiah atas ilmu pengetahuan yang dipelajari.

9. Memprioritaskan ilmu diniyah sebelum memasuki ilmu duniawi.

10. Mengenal nilai-nilai pragmatis bagi suatu ilmu pengetahuan, yaitu ilmu pengetahuan yang dapat bermanfaat, membahagiakan, mensejahterakan, serta memberi keselamatan hidup dunia dan akhirat, baik untuk dirinya maupun manusia pada umumnya. ${ }^{27}$

Dalam hal anak didik, bahwa sifat-sifat umum yang melekat pada anak didik adalah:

a. Anak bukan miniatur orang dewasa. Pandangan klasik berpendapat bahwa anak adalah orang dewasa dalam bentuk kecil (miniatur). Pandangan yang salah ini telah dibantah oleh J.J. Rousseu, yang berpendapat bahwa anak bukan miniatur orang dewasa, tetapi ia adalah hidup dengan dunianya sendiri, yaitu dunia anak yang berlainan sekali dengan alam orang dewasa.

b. Anak didik mengikuti fase-fase perkembangan tertentu, perkembangan dari lahir sampai kedewasaan mengikuti periode-periode perkembangan tertentu. Banyak tokoh yang mengemukakan pembagian fasefase perkembangan ini, antara lain:

1) Kohhustam

a) Masa vital, usia 0-1 tahun

b) Masa estetis, usia 2-7 tahun

${ }^{26}$ Abuddin Nata, Pemikiran Para Toko pendidikan Islam ..., hlm. 99-101.

${ }^{27}$ Samsul Nizar, Filsafat Pendidikan Islam ..., hlm. 52-53. 
c) Masa intelektual, usia 8-13 tahun

d) Masa sosial, usia 14-18 tahun

e) Manusia matang, usia 19 tahun ke atas.

2) Owald kroh

a) Periode pertama dari masa lahir sampai periode pertama, umumnya usia 3 tahun.

b) Periode kedua, sampai periode kedua (anak perempuan 12 tahun, anak laki-laki 14 tahun).

c) Periode ketiga, mulai kedua sampai akhir masa pemuda.

c. Anak didik mempunyai pola perkembangan sendiri. Walaupun di dalam perkembangan anak didik mengikuti fase-fase perkembangan umum, tetapi tiap individu mempunyai pola perkembangan yang berbeda, misalnya tiap anak mempunyai tempo irama perkembangannya sendiri. 28

d. Tugas perkembangan. Anak didik harus melaksanakan tugas perkembangan, yaitu tugas yang harus diselesaikan oleh individu dalam tiap-tiap fase perkembangan. Havigurst mengemukakan tugas perkembangan pada masa bayi dan anak-anak (0-6 tahun) sebagai berikut:

1) Belajar berjalan.

2) Belajar makan-makanan padat.

3) Belajar bercakap-cakap.

4) Belajar menguasai pembuangan kotoran tubuh.

5) Mempelajari perbedaan kelamin dan kelakuan yang sesuai dengan jenisnya.

6) Mencapai stabilitas jasmani.

7) Membetuk pengertian yang sederhana tentang kenyataankenyataan sosial dan alam.

8) Belajar membedakan hal yang benar dan salah serta mengembangkan kata hati atau conciencia.

e. Kebutuhan Anak Didik

Anak didik mempunyai macam kebutuhan pemenuhan kebutuhan ini merupakan syarat yang penting bagi perkembangan pribadi yang sehat.

${ }^{28}$ Khoiron Rosyadi, PendidikanPprofetik....., hlm. 192-197 


\section{Abdul Salam Pulungan}

Macam-macam kebutuhan, antara lain kebutuhan rasa kasih sayang kebutuhan rasa aman, kebutuhan rasa harga diri, kebutuhan kebebasan, kebutuhan sukses, dan kebutuhan ingin tahu.

f. Perbedaan individual

Setiap anak merupakan pribadi tersendiri atau pribadi unik setiap anak berbeda. Di dunia ini tidak ada dua orang anak yang benar-benar sama, walaupun mereka anak kembar yang berasal dari sel telur, perbedaan individual ini disebabkan karena perbedaan faktor indogen (pembawaan) dan eksogen (lingkungannya). ${ }^{29}$

g. Anak sebagai keseluruhan

Sesuai dengan hakekat manusia sebagai makhluk pluralis, maka pribadi anak didik itu walaupun terdiri dari banyak segi tetapi merupakan satu kesatuan jiwa dan raga (cipta dan karsa).

h. Anak didik makhluk aktif dan kreatif.

Anak merupakan makhluk yang memiliki aktivitas dan kreativitas sendiri (daya cipta), sehingga didalam proses pendidikan ia tidak boleh dipandang sebagai objek pasif, tetapi sebagai subjek aktif dan kreatif, yang bereaksi terhadap lingkungan secara selektif.

Berangkat dari fase-fase perkembangan anak didik tersebut di atas, terlihat bahwa secara implisit hal itu menggambarkan perkembangan potensi fitrah yang dimiliki anak didik melalui proses yang berkesinambungan. 30

Akhlak peserta didik/anak didik, sebagaimana disebutkan Asma Hasan Fahmi, ada 4 (empat) macam yang harus dimiliki, yaitu:

1) Seorang anak didik harus membersihkan hatinya dari kotoran dan penyakit jiwa sebelum ia menuntut ilmu, karena belajar adalah merupakan ibadah yang tidak sah dikerjakan kecuali dengan hati yang bersih. Kebersihan hati tersebut dapat dilakukan dengan menjauhkan diri dari sifat-sifat yang tercela, seperti dengki, benci, menghasut, takabbur, menipu, berbangga-bangga, dan memuji diri yang selanjutnya

\footnotetext{
$29 /$ bid.

$30 /$ bid.
} 
diikuti dengan menghiasi diri dengan akhlak yang mulia seperti bersikap benar, takwa, ikhlas, zuhud, merendahkan diri dan ridla.

2) Seorang anak didik harus mempunyai tujuan menuntut ilmu dalam rangka menghiasi juwa dengan sifat keutamaan, mendekatkan diri kepada Tuhan dan bukan untuk mencapai kemegahan dan kedudukan.

3) Seoarang pelajar harus tabah dalam memperoleh ilmu pengetahuan dan bersedia pergi merantau. Selanjutnya apabila ia menghendaki pergi ke tempat yang jauh untuk memperoleh seorang guru, maka ia tidak boleh ragu-ragu untuk itu. Demikian pula ia dinasehatkan agar tidak sering-sering menukar-nukar guru. Jika keadaan menghendaki sebaiknya ia dapat menanti sampai dua bulan sebelum menukar seorang guru.

4) Seorang anak murid wajib menghormari guru dan berusaha agar senantiasa memperoleh kerelaan dari guru, dengan mempergunakan bermacam-macam cara. ${ }^{31}$

\section{Penutup}

Pada hakikatnya, dalam perspektif falsafah pendidikan Islam, semua manusia adalah peserta didik, sebab semua manusia adalah makhluk yang senantiasa berada dalam proses perkembangan menuju kesempurnaan, atau suatu tingkatan yang dipandang sempurna, dan proses itu berlangsung sepanjang hayat. Peserta didik dalam pandangan Islam memang memiliki daya atau potensi untuk berkembang dan siap pula untuk dikembangkan. Oleh karena itu, setiap peserta didik tidak dapat diperlakukan sebagai manusia yang sama sekali pasif, melainkan memiliki kemampuan dan keaktifan yang mampu membuat pilihan dan penilaian, menerima, menolak atau menemukan alternatif lain yang lebih sesuai dengan pilihannya sebagai perwujudan dari adanya kehendak dan kemauan bebasnya.

Dapat dipahami bahwa peserta didik dalam pendidikan Islam adalah setiap manusia yang memiliki kemampuan untuk mengembangkan potensi

31 Abuddin Nata, Filsafat Pendidikan Islam (Ciputat: Logos Wacana IImu, 2001), hlm. 82-83. 


\section{Abdul Salam Pulungan}

dirinya dan masih membutuhkan bimbingan dan didikan orang lain untuk mencapai tujuan hidupnya yang berdasarkan pada hakikat dan fungsi hidupnya, yaitu sebagai hamba Allah dan khalifah Allah di muka bumi.

Sekalipun konsep teori fitrah mengakui bahwa potensi atau dayadaya yang dimiliki peserta didik secara kodrati memang memiliki keaktifan, akan tetapi membiarkannya tumbuh secara alamiah berdasarkan kodratnya sendiri, sangat memungkinkan pertumbuhannya tidak seperti yang diharapkan. Hal yang penting dilakukan oleh seorang anak didik/peserta didik adalah berniat secara ikhlas dalam menuntut ilmu, karena niat itu merupakan dasar bagi setiap amal perbuatan.

Untuk mencapai hasil yang maksimal dalam proses pendidikan, seorang anak didik dituntut untuk memenuhi kode etik tertentu, baik secara langsung maupun tidak langsung, diantaranya belajar dengan niat ibadah kepada Allah SWT, mengurangi kecendrungan pada duniawai dibandingkan masalah ukhrawi, bersikap tawadlu (rendah hati), menjaga pikiran dan pertentangan yang timbul dari berbagai aliran, mempelajari ilmu-ilmu yang terpuji, belajar dengan cara bertahap, mulai mempelajari yang mudah menuju hal yang sukar, belajar ilmu sampai tuntas untuk kemudian beralih pada ilmu lainnya, mengenal nilai-nilai ilmiah atas ilmu pengetahuan yang dipelajari, memprioritaskan ilmu diniyah sebelum ilmu duniawi, mengenal nilai-nilai yang bermanfaat dari suatu ilmu pengetahuan, dan anak didik harus tunduk pada nasehat pendidik.

\section{Daftar Pustaka}

Abdul Mujib, Ilmu Pendidikan Islam, Jakarta: Fajar Interpratama Offset, 2008.

Abuddin Nata, Filsafat Pendidikan Islam, Ciputat: Logos Wacana IImu, 2001.

......., Pemikiran Para Toko pendidikan Islam Seri Kajian Filsafat Pendidikan Islam, Jakarta: Raja Grafindo Persada, 2001.

......... Persfektif Islam tentang Pola Hubungan Guru Murid, Jakarta: Raja Grafindo Persada, 2001.

Persfektif Islam tentang Strategi Pembelajaran, Jakarta: Kencana, 2009. 
Al Rasyidin, Falsafah Pendidikan Islami: Membangun Kerangka Ontologi, Epistomologi dan Aksiologi Praktek Pendidikan, Bandung: Cipta Pustaka Media Perintis, 2008.

Asrorun Niam Sholeh, Reorientasi Pendidikan Islam Mengurai Relevansi Konsep al-Ghazali dalam Konteks Kekinian, Jakarta, 2004.

Dja'far Siddik, Konsep Dasar IImu Pendidikan Islam, Bandung: Citapustaka Media, 2006.

Khoiron Rosyadi, Pendidikan Profetik, Yogyakarta: Pustaka Pelajar, 2004.

M. Irsyad Djuwaeli, Pembaruan Kembali Pendidikan Islam, Ciputat: Karsa Utama Mandiri dan PB Mathla'ul Anwar, 1998.

Ramayulis, IImu Pendidikan Islam, Jakarta: Radar Jaya Offset, 2008.

Samsul Nizar, Filsafat Pendidikan Islam Pendekatan Historis, Teoritis, dan Praktis, Jakarta Selatan: Ciputat Pers, 2002.

Suyadi, "Peserta Didik Zaman Keemasan Islam" dalam Suwito, Sejarah Sosial Pendidikan Islam, Jakarta: Kencana, 2008.

Syafaruddin dkk, IImu Pendidikan Islam, Jakarta: Hijri Pustaka Utama, 2006.

Yunus Namsa, Metodologi Pengajaran Agama Islam, Jakarta: Pustaka Firdaus, 2000. 